\title{
Pre-service teachers' inclusion of climate change education
}

\author{
Ronnel Joseph T. Competente \\ College of Education, University of Nueva Caceres, Philippines
}

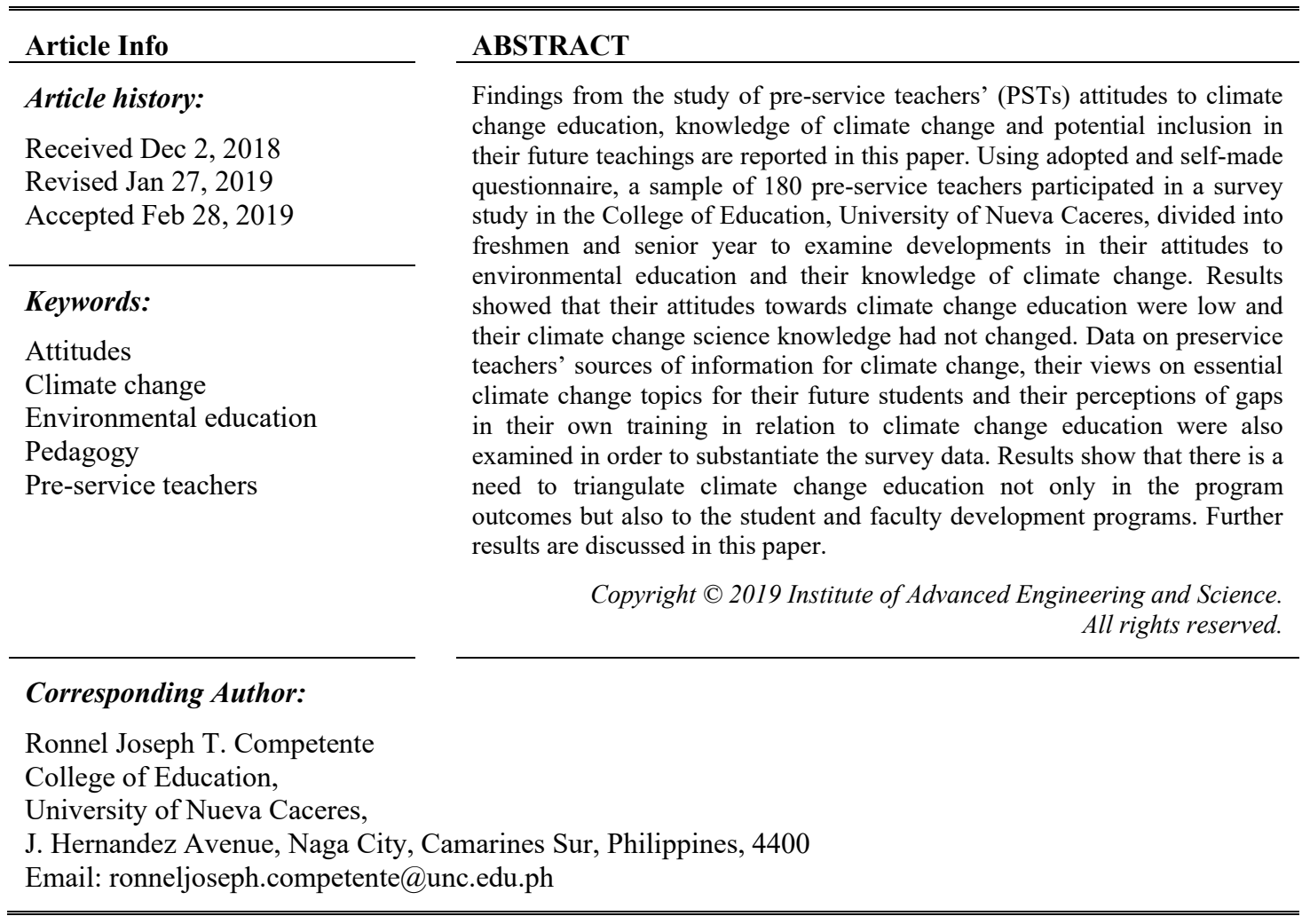

\section{INTRODUCTION}

Climate change is perhaps one of the perilous pressing issues our world is facing today. Across the globe, the effects of climate change are being reported and documented. Although some still refute the fact of the wrath of this global phenomenon, $97 \%$ of the world scientists supports the idea that climate change is undeniably happening. Much concern is in fact laid upon countries like the Philippines. Consistently, climatologists published papers that the Philippines is among the vulnerable countries to the effects of climate change [1]. Surveys showed that 85 percent (or eight out of ten) Filipinos claimed to have "personally experienced" climate change impacts in the last three years. Out of this number, 54\% described their experience as "severe" to "moderate" while 31\% said it was "little." [2]

Since the causes of climate change are linked to anthropogenic activities, these activities need to be first identified so that, for instance, one can reflect on his/her actions and create innovative solutions for this pressing issue. Climate change, as mentioned, is the most important socio-scientific issue that teachers of all age groups could choose to address, given its political and contentious nature is climate change [3]. This is especially important because those who have the least understanding of climate change are most likely to trust sources of information that are untrustworthy and to fail to differentiate between relevant and irrelevant criteria when judging the trustworthiness of sources [4]. Thus, this study was conducted to assess the inclusion of climate change education of pre-service teachers of University of Nueva Caceres College of Education. It investigated the attitudes, knowledge and perception of PST as to climate change and how its content can reflect on their teachings in the future. It assessed the levels of attitude and climate change knowledge of pre-service teachers. Further, it measured the significant differences on attitudes and 
knowledge of first year and senior year students. It also traced the sources of climate change knowledge. The result of this study may assist the college to revisit its curricular offerings and mainstream climate change education to its programs and aims. It may also help in promoting climate change education initiatives in the college and in the whole university to further amplify the need to address the issue of climate change.

\section{RESEARCH METHOD}

This study utilized a mixed method embedded research methodology. The purpose of the embedded research design was to collect both quantitative and qualitative data simultaneously and to have one form of data plays a supportive role to the other form of data. In this case the open ended questions were designed to illuminate PSTs' engagement with climate change by eliciting their views about what knowledge their future students should know, their perceived gaps in knowledge and the sources of their own information, matters not easily captured by the multi-choice knowledge questions.

The study included the first year and fourth year students of College of Education for school year 2016-2017, with a combined population od 180. Using the Slovin formula, sample population was obtained and was surveyed. The PSTs subjected in the surveyed were oriented and were given a consent form for them to fill-out. Only those who signified to be part of the survey were included in the research.

The author used an adopted questionnaire from researches Boon [5] and Caranto and Pitpunge [39] which included simple demographic questions along with Likert's scale questions exploring the participant's attitude to, and self-efficacy for $(\alpha=.71)$, multiple-choice questions testing their perceived and actual knowledge of a range of environmental sustainability issues $(\alpha=.82)$ as well as a checklist of the possible sources of their environmental knowledge. The instrument was constructed with the researchers' knowledge on environmental and science education and educational psychology to ensure its items had appropriate content validity. Permissions for the said questionnaires were asked to the original researchers.

Responses to open-ended questions on the survey were analyzed by the constant comparative method. It was anticipated that these questions would provide insight into PSTs conceptualization of climate change education and the sources of these conceptualization. As for data analysis, the researcher utilized frequency, percentage and ranking to determine the levels of awareness and engagement. One-way MannWhitney (u) test and analysis of variance (f) test were used to test the differences between freshmen and senior year results. Further, the researcher used a Tukey HDD post-hoc analysis to strengthen the confidence level of the relationships.

\section{RESULTS AND ANALYSIS}

\subsection{Attitudes towards inclusion of climate change education of PSTs}

Table 1 summarizes responses to attitudinal questions at the two points in time. Data shows that fourth year students are more confident in preparing accurate learning materials (Q1) with mean of 3.31 over 2.15 of the first year. Surprisingly, first year yielded better scores about inclusion of environmental topics (Q2 3.29 vs 3.04), belief on their role in solving environmental problems (Q3 3.60 vs 3.56) and confidence in the curriculum to teach environmental topics (Q5 3.05 vs 2.52). Both yielded the same score (3.74) on the question about the importance of climate change education to children (Q4).

Table 1. Attitude scores of first and fourth year respondents

\begin{tabular}{|c|c|c|c|}
\hline \multirow{2}{*}{\multicolumn{2}{|c|}{ Survey Questions }} & \multicolumn{2}{|c|}{ Attitude Score } \\
\hline & & $\begin{array}{c}\text { First Year } \\
(n=85)\end{array}$ & $\begin{array}{l}\text { Fourth Year } \\
(n=95)\end{array}$ \\
\hline a. & $\begin{array}{l}\text { I am confident that I can prepare accurate } \\
\text { teaching modules about our environment for } \\
\text { the students that I will be teaching. }\end{array}$ & 2.15 & 3.31 \\
\hline b. & $\begin{array}{l}\text { I cannot include education for our environment } \\
\text { in my teaching because it should be taught by } \\
\text { specially trained teachers. }\end{array}$ & 3.29 & 3.04 \\
\hline c. & $\begin{array}{l}\text { As a teacher, I can play an important role in } \\
\text { solving environmental problems } \\
\text { through teaching. }\end{array}$ & 3.60 & 3.56 \\
\hline d. & $\begin{array}{l}\text { It is very important to educate school students } \\
\text { about our environment from an early age. }\end{array}$ & 3.74 & 3.74 \\
\hline e. & $\begin{array}{l}\text { I do not believe that there is enough time in the } \\
\text { curriculum to fit in education for the } \\
\text { environment as well as everything else we } \\
\text { must teach. }\end{array}$ & 3.05 & 2.52 \\
\hline
\end{tabular}

Int. J. Eval. \& Res. Educ. Vol. 8, No. 1, March 2019: 119 - 126 
The comparison of the scores of the two groups of PST suggests that fourth year students cannot pinpoint specific climate change topics to be discussed to students. But as to specific action towards climate change or clarification of misconceptions, the PSTs are still unaware of what to discuss. In a separate question, the research probed the perceived gaps of students. It should be noted that high scoring respondents gave at least specific topics which they will discuss on their future students. Topics on waste segregation and pollution came up. Also, they highlighted the integration of topics on climate change in their respective fields. CHED Memo No. 33 s 2009 [6] highlighted the importance of integration of climate change education in tertiary curriculum. It can be noted that to some extent, the UNC curriculum has responded to this memorandum, but much investigation is needed on this area. There is a need to append more teaching materials that support climate change topics in teaching science subjects and, if possible, add a climate change lesson or subject to every curriculum or BA/BS degree [7], [8]. Clark theorized the integrative teaching model [9], which posited that if educators will include all human function in our concept of learning, they can plan for more effective and meaningful learning experiences. In this scenario, climate change education can better be achieved if educators will integrate it in their lessons, rather than treating it as a separate subject. Similarly, Kolb theorized a cyclical model of learning on which concretizing experience can be achieved by creating an active action plain to be implemented [10].

There is also a need for the PSTs to be acquainted more with climate change topics. This is crucial since transfer of knowledge is only possible if the educator is well-versed with the topic he/she wants to transfer, which in this case is climate change. Students need to be acquainted with the concept of climate change, causes, effects and mitigation/adaptation strategies for that the teaching could help in disseminating the learned information to other members of the society [11], [12]. Also, the curriculum should ensure a proper way of integration in a particular environmental issue [13], [14]. The researcher believes that UNC's curriculum provides multitude of option on how to address this issue. There is a need to use explicit nature of the pedagogical mode in integrating climate change topics which will require novel methods of teaching, an important component in transmitting knowledge in the future.

An examination of the findings in Table 2 shows that the results of the Mann Whitney $U$ test applied to the responses of the students in the first year and fourth year groups revealed a statistically not significant difference at the level of $\mathrm{p}<.05$ on $\mathrm{Q} 1(\mathrm{Z}=0.34 ; \mathrm{p}=.36<.05)$, Q3 $(\mathrm{Z}=-0.59 ; \mathrm{p}=.28<.05)$ and $\mathrm{Q} 4(\mathrm{Z}=0.006$; $\mathrm{p}=.28<.05)$. Significant difference was posted for $\mathrm{Q} 2(\mathrm{Z}=-1.98 ; \mathrm{p}=.24<.05)$ and $\mathrm{Q} 5(\mathrm{Z}=-3.68 ; \mathrm{p}=.0001<.05)$. The analyses had shown not significant difference between the rank averages of the groups' scores; however, an examination of the rank averages of their scores demonstrates that the students in the first year had higher attitude scores than those in the fourth year. This result indicates that the first year students believed that they have better attitude when compared to their peers in the first year.

Table 2. Results of the Mann Whitney U test to compare the groups' attitudinal scores

\begin{tabular}{|c|c|c|c|c|c|c|c|c|}
\hline \multirow[b]{2}{*}{ QUESTIONS } & \multicolumn{2}{|c|}{ Rank Average } & \multicolumn{2}{|c|}{ Sum of Ranks } & \multirow[b]{2}{*}{$\mathrm{u}$} & \multirow[b]{2}{*}{$\begin{array}{c}\mathrm{z} \\
\text { (one-tailed) }\end{array}$} & \multirow[b]{2}{*}{$\begin{array}{c}\mathrm{p} \\
(\mathrm{p}>.05)\end{array}$} & \multirow[b]{2}{*}{ Interpretation } \\
\hline & $\begin{array}{c}\text { First } \\
\text { Year } \\
(n=85)\end{array}$ & $\begin{array}{c}\text { Fourth } \\
\text { Year } \\
(n=95)\end{array}$ & $\begin{array}{l}\text { First } \\
\text { Year } \\
(n=85)\end{array}$ & $\begin{array}{c}\text { Fourth } \\
\text { Year } \\
(n=95)\end{array}$ & & & & \\
\hline 1 & 89.11 & 91.75 & 7574 & 8716 & 3919 & 0.34 & 0.36 & Not Significant \\
\hline 2 & 98.74 & 83.22 & 8354 & 7906 & 3346 & -1.98 & 0.24 & Significant \\
\hline 3 & 92.93 & 88.33 & 7899 & 8391 & 3831 & -0.59 & 0.28 & Not Significant \\
\hline 4 & 90.47 & 90.53 & 7690 & 8600 & 4035 & 0.006 & 0.496 & Not Significant \\
\hline 5 & 104.73 & 76.19 & 8692.5 & 7238.5 & 2678.5 & -3.68 & 0.0001 & Significant \\
\hline
\end{tabular}

Despite the inclusion of subjects specifically focused on sustainability and a science pedagogy subjects (Natural Science, Ecology, Organismic, etc), not significant relationship was established on the confidence to teach about the environment in this sample of PSTs, recalling prior findings of the review literatures [5], [15], [16]. Alternatively, it is possible that they did not pay attention to the issues relating to climate change per se but instead focused on other topics included in their study of sustainability. Although they believed that the curriculum prepared them to become climate change advocates, it doesn't translate into concrete knowledge. Note that it is important for the improvement of systems on monitoring, documenting and evaluating of academic program evaluation process, lessons and modules implementation process, environmental education practice, general school operation of EE and formation of the academic community for academic education [16]. Also, relatively congruent results of similar researches posted not significant relationship between perceived knowledge and actual knowledge which suggested that the participants either do not feel constrained by their lack of knowledge, or are perhaps unaware of their actual knowledge of sustainability issues [15]. It can be emphasized that personal interest was key to engagement with climate change education. This seemed to be associated with active involvement in implementing sustainability units 
through professional experience [5]. The college should rally awareness activities towards climate change if it wants its produce to integrate climate change topics in their teaching.

\subsection{Awareness of PSTs in climate change}

Table 3 summarizes the scores of the respondents. Most of the respondents $(50.1 \%$ for freshman and $53.7 \%$ for seniors) posted only scores from $6-10$, which by standards considered as low scoring range. Only few (10.1\% for freshman and $2.1 \%$ seniors) reached the high scoring range of $16-20$. This indicates a low awareness of the students on climate change. When the significant difference was tested, not significant difference $(\mathrm{F}=3.3953, \mathrm{p}<0.0670)$ was posted. Meaning the scores of the seniors was not affected by the PST program since the freshman scores did not influence the seniors' scores.

Table 3. Range of scores of PSTs in climate change questionnaire

\begin{tabular}{|c|c|c|c|c|c|c|c|c|c|c|}
\hline \multirow[t]{2}{*}{ RANGE } & \multicolumn{4}{|c|}{ FIRST YEAR } & \multicolumn{4}{|c|}{ FOURTH YEAR } & \multirow{2}{*}{\multicolumn{2}{|c|}{ ANOVA }} \\
\hline & & & Mean & SD & & & Mean & SD & & \\
\hline $0-5$ & 8 & 9.4 & & & 16 & 16.8 & & & & \\
\hline $6-10$ & 43 & 50.1 & 100471 & 40617 & 51 & 53.7 & 90211 & 3.4052 & $\mathrm{~F}=(1,178) 3.3953$ & Not \\
\hline $11-15$ & 25 & 29.4 & & & 26 & 27.4 & 9.0211 & 3.4052 & $p>0.0670$ & Significan \\
\hline $16-20$ & 9 & 10.1 & & & 2 & 2.1 & & & & \\
\hline
\end{tabular}

Tables 4 to 7 shows the different number of correct responses of PSTs in the climate change knowledge awareness questions. The questions were comprised of 20 -item multiple choice questions.

Table 4. Number of correct responses on the definition of climate change questions

\begin{tabular}{|c|c|c|c|c|c|c|c|c|c|c|}
\hline \multirow{2}{*}{ ITEM } & \multicolumn{4}{|c|}{ First Year } & \multicolumn{4}{|c|}{ Fourth Year } & \multirow{2}{*}{\multicolumn{2}{|c|}{ ANOVA }} \\
\hline & $\mathrm{CR}$ & $\%$ & Mean & SD & $\mathrm{CR}$ & $\%$ & Mean & SD & & \\
\hline 18 & 50 & 58.8 & & & 54 & 56.8 & & & & \\
\hline 19 & 42 & 49.4 & 46.3333 & 4.0415 & 32 & 33.7 & 46.000 & 12.1655 & $\mathrm{~F}=(1,4) 0.00203$ & Not \\
\hline 20 & 47 & 53.3 & 40.3303 & 4.04113 & 52 & 54.7 & 40.000 & 12.1035 & $\mathrm{p}<0.9662$ & Significant \\
\hline TOTAL & 139 & 54.5 & & & 138 & 48.4 & & & & \\
\hline
\end{tabular}

Table 5. Number of correct responses on the sources of greenhouse gases questions

\begin{tabular}{ccccccccccc}
\hline \multirow{2}{*}{ ITEM } & \multicolumn{9}{c}{ First Year } & \multicolumn{6}{c}{ Fourth Year } & \multicolumn{2}{c}{ ANOVA } \\
& CR & $\%$ & Mean & SD & CR & $\%$ & Mean & SD & & \\
\hline 1 & 55 & 64.7 & & & 42 & 44.2 & & & F $=(1,4)$ & Not \\
2 & 70 & 82.4 & 48.6667 & 25.1064 & 71 & 74.7 & 43.0000 & 27.5136 & 0.0694 & Significant \\
6 & 21 & 24.7 & & & 16 & 16.8 & & & $\mathrm{p}<0.8052$ & \\
TOTAL & 146 & 57.2 & & & 129 & 45.3 & & & \\
\hline
\end{tabular}

Table 6. Number of correct responses on the effects of climate change questions

\begin{tabular}{|c|c|c|c|c|c|c|c|c|c|c|}
\hline \multirow{2}{*}{ ITEM } & \multicolumn{4}{|c|}{ First Year } & \multicolumn{4}{|c|}{ Fourth Year } & \multicolumn{2}{|c|}{ ANOVA } \\
\hline & $\mathrm{CR}$ & $\%$ & Mean & SD & $\mathrm{CR}$ & $\%$ & Mean & SD & & \\
\hline 3 & 39 & 45.9 & & & 37 & 38.9 & & & & \\
\hline 5 & 44 & 51.8 & & & 55 & 57.9 & & & & \\
\hline 7 & 30 & 35.3 & & & 38 & 40.0 & & & & \\
\hline 8 & 24 & 28.2 & 37.5000 & 14.2513 & 34 & 34.7 & 40.6667 & 16.3054 & 0.1283 & Not \\
\hline 12 & 26 & 30.6 & & & 17 & 17.9 & & & $\mathrm{p}<0.7277$ & Significant \\
\hline 16 & 62 & 72.9 & & & 63 & 66.3 & & & & \\
\hline TOTAL & 163 & 31.6 & & & 244 & 42.8 & & & & \\
\hline
\end{tabular}

Table 7. Number of correct responses on the mitigation and adaptation of Philippines to climate change

\begin{tabular}{|c|c|c|c|c|c|c|c|c|c|c|}
\hline \multirow{2}{*}{ ITEM } & \multicolumn{4}{|c|}{ First Year } & \multicolumn{4}{|c|}{ Fourth Year } & \multirow{2}{*}{\multicolumn{2}{|c|}{ ANOVA }} \\
\hline & $\mathrm{CR}$ & $\%$ & Mean & SD & $\mathrm{CR}$ & $\%$ & Mean & SD & & \\
\hline 4 & 33 & 38.8 & \multirow{9}{*}{43.0000} & \multirow{9}{*}{12.9725} & 24 & 25.3 & \multirow{9}{*}{42.375} & \multirow{9}{*}{19.8418} & \multirow{9}{*}{$\begin{array}{c}\mathrm{F}(1,14) \\
=0.00556 \\
\mathrm{p}<0.9416\end{array}$} & \multirow{9}{*}{$\begin{array}{c}\text { Not } \\
\text { Significant }\end{array}$} \\
\hline 9 & 33 & 38.8 & & & 23 & 24.2 & & & & \\
\hline 10 & 49 & 57.6 & & & 50 & 52.6 & & & & \\
\hline 11 & 61 & 78.1 & & & 64 & 67.4 & & & & \\
\hline 13 & 52 & 61.6 & & & 58 & 61.1 & & & & \\
\hline 14 & 21 & 24.7 & & & 14 & 14.7 & & & & \\
\hline 15 & 45 & 52.9 & & & 42 & 44.2 & & & & \\
\hline 17 & 50 & 58.8 & & & 64 & 67.4 & & & & \\
\hline TOTAL & 344 & 50.6 & & & 339 & 44.6 & & & & \\
\hline
\end{tabular}

Int. J. Eval. \& Res. Educ. Vol. 8, No. 1, March 2019: 119 - 126 
These results show that PST program lacked the capability to inject climate change education in their professional subjects. Although not explicit, climate change education was highlighted by CHED in its Higher Reform Agenda [17] and emphasized the roles of HEIs in attaining the National Climate Change Action plan 2011-2028. Scholars argue that higher education plays a critical role in preparing and providing the leadership to meet challenges in these areas [6], [18]-[20]. Universities are strategically located to enhance research and development programs for climate change, increase warm bodies prepared to extend technical services, educating the public and preparing the country and to have meaningful inclusion in climate change policy decisions. Also, it is discovered that although majority of teachers demonstrated significantly high literacy levels regarding climate change science, some gaps in teachers' knowledge of climate change science were evident. Climate change science is characterized by a measure of uncertainty; and that incidences of diseases in some developing countries are not solely due to climate change [21]. Although the pre-service teachers appear to have a sound understanding of the actions that will help to reduce global warming and are well positioned to inform their students about these, their potential as role models might be compromised if their own actions are not in line with their understanding [22]. Also, local knowledge and practices can play in reducing risk and improving disaster preparedness is now acknowledged by disaster risk reduction specialists [23], [24] It is a must to consider exogenous factors that might affect CC education by taking into account those that are equally capable of shaping students' perception and knowledge. This process is unique in that it allows communities to identify knowledge that can be integrated with science, which could then be further disseminated for use by scientists, practitioners and policy-makers, and safeguard and valorize those that cannot be scientifically explained. Hands-on activities, tying it up with community services, holding symposia and for other activities would help to increase these mainstreaming of climate change education.

Alternative explanation for the results of this study might be connected with the actual pedagogy of the tertiary educators of these PSTs. It is difficult to know to what extent university educators have adopted a "balanced" view when presenting materials to PSTs in relation to climate change and sustainability despite the university's pro-environmental and pro-climate change stance [5]. Also, PSTs may have lacked the capacity to influence their students in the future, which may lead to their future students' unenthisasistic regard for climate change, as posited by Bronfenbrenner's theory [25]. Adding to that is the media, up until most recent times, presented a undecided view of climate change science, with a focus on reporting climate change sceptics' perspectives on climate change. This is somehow alarming since some studies strongly argues that schools are the main drivers of the general public's awareness on climate change. Climate change science must be incorporated into pre-service teacher training if the science is to be accurately and appropriately communicated to school children and adolescents [5]. But alongside with that are the faculty development workshops to be conducted to prepare and educate a cadre of faculty from different disciplines in global climate science literacy. An approach was tried among the pre-service educators and faculty members [26]. Program evaluation confirms that the workshop participant shows improved understanding of the workshop materials by the participants if they were introduced few climate topics. Learning how to use hands-on learning tools and preparing lesson plans are two of the challenges successfully implemented by the pre-service teachers. This will mutually help the school science teachers to learn and use the materials provided by the pre-service teachers and also pre-service teachers to improve their teaching skills on climate change content.

\subsection{Sources of information of PSTs on climate change knowledge}

Table 8 summarizes the responses of the students as to their sources of information on climate change. It shows that the respondents got most of their climate change ideas in the Internet, with the exception of social media sites, second is programs on television and third in teachers. The least sources they chose were politician, church authorities and community elders. The results revealed that indirectly, the students garnered their idea of climate change through, perhaps, school works. Both areas which attributed to it (teachers and Internet use).

Round up to the top responses. We can loosely say that climate change was part of the topics they could have encountered in their paper works, although further investigation in needed to prove this proposition. It also indicates strong indication of how influential the school is in shaping the ideas of the students in climate change. Integrating climate change curriculum into preservice elementary science methods courses help improve awareness in schools [18], [26]. Overall, students' views about global climate change shifted toward being more concerned. This is a significant result and implies that, since these preservice teachers will soon be teaching our youth in schools, this may be a good start to overcoming public misunderstandings about global climate change. 


\begin{tabular}{|c|c|c|c|c|c|c|}
\hline Sources & $\begin{array}{l}\text { First } \\
\text { Year }\end{array}$ & Rank & Fourth Year & Rank & Rank Score & TOTAL RANK \\
\hline TV & 84.7 & 2 & 88.4 & 1 & 3 & 2 \\
\hline Radio & 47.1 & 7 & 54.7 & 5 & 12 & 7 \\
\hline Internet & 90.6 & 1 & 88.4 & 1 & 2 & 1 \\
\hline Newspaper & 50.6 & 5 & 49.5 & 6 & 11 & 6 \\
\hline Social Media Websites & 72.9 & 4 & 68.4 & 3 & 7 & 4 \\
\hline Magazines & 30.6 & 10 & 32.6 & 9 & 19 & 10 \\
\hline Politicians & 14.1 & 13 & 14.7 & 13 & 26 & 14 \\
\hline Family Members & 40.0 & 8 & 44.2 & 7 & 15 & 8 \\
\hline Church Authority & 15.3 & 12 & 20.0 & 12 & 24 & 13 \\
\hline Community Elders & 28.2 & 11 & 21.1 & 11 & 22 & 12 \\
\hline Teachers & 82.4 & 3 & 76.8 & 2 & 5 & 3 \\
\hline Schoolmates & 36.5 & 9 & 41.1 & 8 & 17 & 9 \\
\hline School Authority & 28.2 & 11 & 30.5 & 10 & 21 & 11 \\
\hline $\begin{array}{l}\text { Environmentalist/Experts thru } \\
\text { Seminars }\end{array}$ & 48.2 & 6 & 63.2 & 4 & 10 & 5 \\
\hline Others & 3.5 & & 0 & & & \\
\hline
\end{tabular}

The schools should be equipped with relevant learning materials to ensure students have an access to correct information on climate change. The teachers should be in- serviced to able to effectively teach climate change topics. The integrated environmental education should be reviewed to include more climate change topics [27]-[29]. Findings pointed out there is the need for an urgent strengthening of extension arm in terms of climate change education. This will help to align the students' knowledge and correct their misconceptions. Another area to be considered are rallying climate change as socioscientific concern - a social dilemmas with conceptual and technological ties to science [30]. These issues are controversial in nature because they require an individual to draw on personal content knowledge and moral reasoning to choose a position with an unclear outcome corroborated this by claiming that two issues are involved. In effect, the college has a moral responsibility to re-examine ethical considerations when developing lessons involving climate change. Educators should also involve students in identifying adaptation strategies to cope with the impacts of climate change [31], [32]. They should provide opportunities for the students to evaluate impacts of climate change and create models on how to adapt to the change. Educators should not limit their presentations, instructions and teachings on daily temperature or daily weather conditions but on global data. As also narrated in the earlier analysis, integrated or holistic approaches to program design have also been shown to create better opportunities for communication between PSTs and the curriculum. Some recommends an integrated approach in program design that is more reflective of an authentic teaching situation where disciplines overlap that a conceptual framework that promotes a fragmented teacher education program [33]-[35].

Currently, the related government agencies are committed in informing the public about climate change. Flagship programs includes KLIMA and Earth Hour [36]. But much has to be done to trickle this glaring concern down to the public. There is also a strong recommendation that the HEIs should include climate change awareness or sustainable development as part of the Philippine education curriculum [37], [38]. Research and development particularly the causes and impacts of climate change are important and universities are crucial in attaining this goal.

\section{CONCLUSION}

The study concludes that were unsure on how to include climate change topics since they lack the content and skill requirement to do so. PSTs need an in-depth knowledge and hands-on activities to include climate change education in their future teachings. The findings of the present study reveal that PSTs have low awareness on climate change. Much has to be done to correct misconception and analyze appropriate measures in mitigation and adaptation suited in the Philippine setting. The university is still the best source of climate change knowledge for PSTs. It is indeed a barometer of how PSTs will transmit their knowledge to their future students. There is a need for the curriculum to be more responsive in supplying activities to students to increase its awareness on climate change education. The role of the university is also crucial in funneling topics to be shared by these PSTs on climate change education. Further training of students, teaching staff and even the administration is much needed. As we know, PSTs are the future educators of the country. Instilling and equipping them with the right mind set on climate change will really make a difference in our combat against global warming.

Int. J. Eval. \& Res. Educ. Vol. 8, No. 1, March 2019: 119 - 126 


\section{ACKNOWLEDGEMENTS}

The author would like to extend his gratitude to the Office of Academic Vice President Research Division for the help extended to conduct this study.

\section{REFERENCES}

[1] Bradsher, K., "The Paris Agreement on Climate Change Is Official," Now What?. New York Times, pp. B3. Retrieved from https:/www.nytimes.com/2016/11/04/business/energy-environment/paris-climate-changeagreement-official-now-what.html? r=0, 2017.

[2] Ranada, P.," 72\% of Filipinos 'very concerned' about climate change - survey," Rappler, Retrieved November and December $2016 \mathrm{http} / \mathrm{www}$. rappler.com/environment/Filipinos_very_concerned_about_climate_change, Aug 2015.

[3] Dawnson, V., and Carson, K., "Australian secondary school students' understanding of climate change," Teaching Science, vol. 59(3), pp. 9-14, 2013.

[4] Bråten, I., Strømsø, H., and Salmerón, L., "Trust and mistrust when students read multiple information sources about climate change," Learning And Instruction, vol. 21(2), pp. 180-192, [Online] available: http://dx.doi.org/10.1016/j.learninstruc.2010.02.002, 2011.

[5] Boon, H., "Pre-Service Teachers and Climate Change: A Stalemate?," Australian Journal Of Teacher Education, vol. 41(4), pp. 39-63, [Online] available: http://dx.doi.org/10.14221/ajte.2016v41n4.3, 2016.

[6] Perez, R.," Climate Change in the Philippines," De La Salle University Symposium in the Economics of Climate Change in Southeast Asia, Retrieved from http://www.dlsu.edu.ph/research/centers/aki/_pdf/_conferences/climateChangePresentation.pdf, 2009.

[7] Commission on Higher Education, "Integration of Environmental Education in the Tertiary Education Curriculum," 2009.

[8] Bunten, R. and Dawnson, V., "Teaching climate change science in senior secondary school: Issues, barriers and opportunities," Teaching Science, vol. 60(1), 1st ser., pp. 10-38, 2014.

[9] Nibalvos, A.V., Pinarok, N.A., and.Dala, D., "Integration Of Climate Change Topics In Teaching Science-Related Subjects At Eastern Samar State University - Borongan Campus," Imperial Journal Of Interdisciplinary Research, vol. 2(10), 2016.

[10] Clark, B., "Putting the pieces together in a working model," Transforming Education, vol. 44, 1988.

[11] Davey K.,"Experiential Learning (Kolb)," in Learning Theories, Retrieved froom https://www.learningtheories.com/experiential-learning-kolb.html, 2007.

[12] Garcia, M. and Garcia, M., "Need for Environmental Literacy," Philippine Daily Inquirer, Retrieved Marc and Apr, 2017, from http://opinion.inquirer.net/97833/need-for-environmental-literacy, Oct 2016.

[13] Doelle, M., "Integration among Global Environmental Regimes: Lessons Learned from Climate Change Mitigation," SSRN Electronic Journal, Retrieved from http://dx.doi.org/10.2139/ssrn.2173244, 2009.

[14] Oversby, J., "Teachers' Learning about Climate Change Education," Procedia - Social And Behavioral Sciences, vol. 167, pp. 23-27, Retrieved from http://dx.doi.org/10.1016/j.sbspro.2014.12.637, 2015.

[15] Effeney, G., and Davis, J., "Education for Sustainability: A Case Study of Pre-service Primary Teachers' Knowledge and Efficacy," Australian Journal Of Teacher Education, vol. 38(5), [Online] available: http://dx.doi.org/10.14221/ajte.2013v38n5.4, 2013.

[16] Villanueva, G., "The Extent of Integration of Environmental Education in the Curriculum of Miriam College High School," The International Journal Of Sustainability Education, vol. 8(1), pp. 47-61, [Online] available: http://dx.doi.org/10.18848/2325-1212/cgp/v08i01/55305, 2013.

[17] Commission on Higher Education. (2011). Higher Education Reform Agenda (2011-2015).

[18] Bernardo, E., "Curriculum Enhancement and Biodiversity [Abstract]," Isabela State University Journal, Retrieved Feb. and March, 2017.

[19] Lawas, T., Coladilla, J. and Espaldon, M.V., "Role of SCUs in the Philippines in the Context of Climate Change and Initial Experiences for Integration in Elementary and High School Curriculum," SESAM-UPLB (University of The Philippines Los Banos), Retrieved from http://19.92.161.2/portal/Portals/20/Patlepam/14thclark/LawasMainstreaming\%20CC-Role\%20of\%20Univ\%20in\%20RP.pdf, 2009.

[20] De Leon, E.G., "Barriers in Scaled Climate Change Adaptation Policy in the Philippines," United Nations Peace and Progress, vol. 3(1), pp. 32-43, Retrieved from http://postgraduate.ias.unu.edu/upp/wpcontent/uploads/2016/07/4 De-Leon article.pdf, 2016.

[21] Ikeh, M., Ifeanyieze, F., and Ugwuoke, C., "Integration of Climate Change into the Senior Secondary School Agricultural Science Curriculum in Nigeria," Atmospheric And Climate Sciences, vol. 4(4), pp. 614-621, [Online] available: http://dx.doi.org/10.4236/acs.2014.44054, 2014.

[22] Álvarez-García, O., Sureda-Negre, J., and Comas-Forgas, R., "Environmental Education in Pre-Service Teacher Training: A Literature Review of Existing Evidence," Journal Of Teacher Education For Sustainability, vol. 17(1), [Online] available: http://dx.doi.org/10.1515/jtes-2015-0006, 2015.

[23] Hiwasaki, L., Luna, E., Syamsidik, and Shaw, R., "Process for integrating local and indigenous knowledge with science for hydro-meteorological disaster risk reduction and climate change adaptation in coastal and small island communities," International Journal Of Disaster Risk Reduction, vol. 10, pp. 15-27, Retrieved from http://dx.doi.org/10.1016/j.ijdrr.2014.07.007, 2014. 
[24] Manalo, J., Balmeo, K., Berto, J., Saludez, F., Villaflor, J., and Pagdanganan, A., "Integrating climate-smart rice agriculture into secondary-level curriculum: lessons from three high schools in the Philippines," Springerplus, vol. 5(1), Retrieved from http://dx.doi.org/10.1186/s40064-016-3238-6, 2016.

[25] Doelle, M., "Integration among Global Environmental Regimes: Lessons Learned from Climate Change Mitigation," SSRN Electronic Journal, Retrieved from http://dx.doi.org/10.2139/ssrn.2173244, 2009.

[26] Ozbay, G., Fox-Lykens, R., Veron, D. E., Rogers, M., Merrill, J., Harcourt, P., and Mead, H., "Minority Pre-service Teachers' and Faculty Training on Climate Change Education in Delaware State University," American Geophysical Union, Retrieved from http://adsabs.harvard.edu/abs/2015AGUFMED33A0931O, 2015.

[27] Bleicher, R., and Lambert, J., "Preservice Teachers' Perspectives on Global Climate Change," The International Journal Of Climate Change: Impacts And Responses, vol. 4(1), pp. 65-72, Retrieved from http://dx.doi.org/10.18848/1835-7156/cgp/v04i01/37152, 2013.

[28] Bell, S., and Potempa, K., "Implementing climate change and health into pre-service nursing education," Annals Of Global Health, vol. 82(3), pp. 438-439, Retrieved from http://dx.doi.org/10.1016/j.aogh.2016.04.215

[29] Adebisi-Adelani, O., and Oyesola, O., "Information Sources and Awareness of Climate Change by Citrus Farmers in Benue State," Journal Of Agricultural Extension, vol. 18(2), pp. 1, Retrieved from http://dx.doi.org/10.4314/jae.v18i2.1, Nigeria 2014

[30] Cajigal, A. and Tippins, D., "Epistemological and Pedagogical Beliefs of Preservice Secondary Science Teachers on Global Climate Change," MMSU Science and Technology Journal, vol. 3(1), 2013.

[31] Pitpitunge, A., "Students' Perception About Climate Change," Asian Journal of Biology Education, vol. 7(1), Retrieved from http://www.aabe.sakura.ne.jp/Journal/Papers/Vol7/02\%20Pitpitunge.pdf, 2013.

[32] Reser, J. and Swim, J., "Adapting to and coping with the threat and impacts of climate change," American Psychologist, vol. 66(4), pp. 277-289, Retrieved from http://dx.doi.org/10.1037/a0023412, 2011.

[33] Northcote, M. and Lim, P., "The State of Pre-service Teacher Education in the Asia-Pacific Region," Retrieved from: https://www.researchgate.net/publication/49280642_The_state_of_preservice_teacher_education_in_the_Asia-Pacific_region, 2014.

[34] Pandey, N. and Vedak, V., "Structural transformation of education for sustainable development," International Journal Of Environment And Sustainable Development, vol. 9(1/2/3), pp. 3, Retrieved from http://dx.doi.org/10.1504/ijesd.2010.030063, 2010.

[35] Therriault, G. and Harvey, L., "Epistemological beliefs and their relationship to the knowledge of preservice secondary school teachers," PROSPECTS, vol. 43(4), pp. 441-459, Retrieved from http://dx.doi.org/10.1007/s11125-013-9288-4, 2013.

[36] Gichuki, M., "Awareness and Sources of Climate Change Information among Secondary Students in Nairobi County", Kenyatta University Journal, vol. 117. Retrieved from http://ir-library.ku.ac.ke/handle/123456789/13402, Kenya 2014.

[37] Inter-Agency Committee on Climate Change (IACCC), "Climate Change Public Awareness and Communication: The Philippine Experience," Environmental Management Bureau-Department of Environment and Natural Resources, Retrieved from http://www.env.go.jp/en/earth/apnet/documents/seminar/15th/philippines_rws1_050913.pdf, 2015.

[38] Bendijo, J. V., Lucero, D. S., and Rubino, A. A., "Global Warming in the Philippines: The Effects and Challenges To Its Economy, Natural Resources, and Government Policies," Retrieved Jan. and Feb., 2017, from http://joelvbendijo.blogspot.com/2012/02/global-warming-in-philippines-effects.html, 2012.

[39] Caranto, Brenda and Pitpitunge, Arnold D. Students' Knowledge On Climate Change: Implications On The K-12 Science Interdisciplinary Learning. In: Gnanamalar Sarojini Daniel E. (eds) Biology Education and Research in a Changing Planet. Springer, Singapore, 2013

\section{BIOGRAPHY OF AUTHOR}

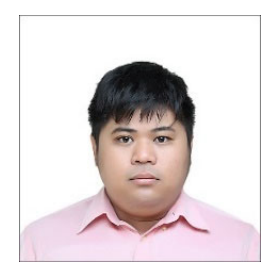

Ronnel Joseph T. Competente is a currently studying of Doctor of Education in Educational Management and a graduate of Master of Science in Environmental Science with Specialization in Chemistry and Biology in 2015 at the University of Nueva Caceres, Naga City, Philippines. He earned Bachelor of Secondary Education major in Biological Science in 2010 at the same university. He is a high school teacher for six years at Tinago National High School, Naga City, Philippines. He is also Associate Professor at University of Nueva Caceres teaching Physical Science, General Biology and Environmental Science among non-majors. Science teaching and development of research culture are the focus of his research works.

Int. J. Eval. \& Res. Educ. Vol. 8, No. 1, March 2019: 119 - 126 